\title{
PROTEASE PRODUCTION DURING GROWTH AND AUTOLYSIS OF SUBMERGED METARHIZIUM ANISOPLIAE CULTURES
}

\author{
Gilberto U.L. Braga*; Ricardo H.R. Destéfano; Claudio L. Messias \\ Departamento de Genética e Evolução, Instituto de Biologia, Universidade Estadual de Campinas, \\ Campinas, SP, Brasil
}

Submitted: July 03, 1998; Returned to authors for corrections: January 28, 1999; Approved: April 08, 1999

\begin{abstract}
The growth and autolysis of two strains of the entomopathogenic deuteromycete fungus Metarhizium anisopliae var. anisopliae were evaluated in medium containing casein or glucose as carbon source. Parameters such as economic coefficient and degree of autolysis were determined for each strain. Protease production was determined throughout the growth and autolysis phases of the cultures on medium under conditions of protease induction (in the presence of casein as sole source of carbon and nitrogen). The fungus was shown to utilize casein as a carbon/energy source in a more efficient manner than glucose. The autolysis shown by the strains was intense under both types of growth conditions, reaching up to $62.7 \%$ of the dry mass produced and started soon after the depletion of the exogenous carbon source. The relationship between the proteolytic activities of the two strains evaluated varied significantly (a maximum of 19.78 on the $5^{\text {th }}$ day and a minimum of 2.03 on the $16^{\text {th }}$ day of growth) during the various growth and autolysis phases, clearly showing that the difference between the growth curves and the difference in the kinetics of enzyme production may decisively affect the process of strain selection for protease production.
\end{abstract}

Key words: Metarhizium anisopliae, protease production, fungal growth, fungal autolysis, entomopathogenic fungus

\section{INTRODUCTION}

Fungi have been extensively used as producers of different substances of economic interest such as enzymes, antibiotics, vitamins, amino acids and steroids. In many cases, the metabolites produced in culture play an important role in the physiological processes of the microorganism in the environment. This is the case for the hydrolytic enzymes and the toxines produced by the entomopathogenic deuteromycete fungus $M$. anisopliae which, in addition to being of economic interest, are important during the process of host penetration and death. However, the evaluation of the production of these substances and the use of these parameters in programs of selection and genetic breeding of different strains depend on the understanding of the basic aspects related to their development in culture.

Several studies have associated protease production (more specifically chymoelastases acting on insect cuticles or proteases with a toxic action) with the virulence of $M$. anisopliae $(4,6,7,8,23)$.

\footnotetext{
* Corresponding author. Mailing address: Departmant of Biology, Utah State University, 5305, University Blvd, Logan, Utah, USA
} 
The existence of wide genetic variability in the production of these enzymes has also been observed $(2,13,19)$. For practical reasons, most of the studies on enzyme production are limited to a single evaluation performed after a given period of growth. On this basis, we may assume that factors such as the differences between the growth curves of the isolates or the difference in the kinetics of enzyme production by the strains may hamper comparison and selection for the trait of interest.

The objective of the present study was to determine the kinetics of protease production by $M$. anisopliae strains during culture growth and autolysis.

\section{MATERIALS AND METHODS}

\section{Origin and maintenance of the strains}

Strains CLII and 22 of M. anisopliae var. anisopliae were obtained from the germplasm bank of the laboratory of entomopathogenic fungi of the State University of Campinas - UNICAMP. Strain CLII was isolated in the state of Alagoas, Brazil, from the sugar cane leaf spittlebug Mahanarva posticata (Homoptera: Cercopidae) and strain 22 was isolated in the state of Espírito Santo, Brazil, from pasture spittlebug Deois flavopicta (Homoptera: Cercopidae). To obtain spores, the strains were grown on complete solid medium (CSM) (14) at $28^{\circ} \mathrm{C}$ for 12 days.

\section{Growth conditions}

Fifty $\mathrm{ml}$ Erlenmeyer flasks containing $30 \mathrm{ml}$ culture medium were inoculated with $3 \mathrm{ml}$ of a suspension containing $3 \times 10^{7}$ conidia $\mathrm{ml}^{-1}$ in an aqueous solution containing $0.85 \% \mathrm{NaCl}(\mathrm{w} / \mathrm{v})$ and $0.002 \%$ Tween-20 (v/v). The flasks were then incubated at $28^{\circ} \mathrm{C}$ with shaking at $150 \mathrm{rpm}$ for variable periods of time (1 to 16 days). After each incubation period, the content of each flask was filtered through Inlab type 10 paper, previously washed and tared, in order to retain the mycelial mass produced. The collected filtrate was divided into 1 $\mathrm{ml}$ aliquots and stored at $-70^{\circ} \mathrm{C}$. The presence of possible contaminants was monitored throughout the experiment by microscopic observation of the filtrate and by plating aliquots of the medium onto dishes containing CSM. Controls containing culture medium only were used to determine the changes in medium volume over the 16 days of incubation. All experiments were carried out in triplicate.

The two carbon sources (glucose and casein, Hammarsten, vitamin free) were added individually to basic salt medium (14) at a concentration of $0.5 \%$ $(\mathrm{w} / \mathrm{v})$. When casein was used, $\mathrm{NaNO}_{3}$ was eliminated. The media were sterilized by autoclaving at $121^{\circ} \mathrm{C}$ for $20 \mathrm{~min}$.

\section{Determination of proteolytic activity against casein}

Caseinolytic activity was determined as shown by Söderhäl and Unestam (21), with the following modifications: test tubes containing $1 \mathrm{ml}$ of the filtrate were incubated in a water bath at $30^{\circ} \mathrm{C}$. After $5 \mathrm{~min}, 1 \mathrm{ml}$ of a $2 \%(\mathrm{w} / \mathrm{v})$ vitamin-free casein (Hammarsten) solution in $0.05 \mathrm{M}$ Tris- $\mathrm{HCl}$ buffer, $\mathrm{pH} 8.0$, of the same temperature was then added to each tube. The mixture was incubated at $30^{\circ} \mathrm{C}$ for 15 minutes without shaking. The reaction was stopped by the addition of $5 \mathrm{ml}$ of a $10 \%(\mathrm{w} / \mathrm{v})$ trichloroacetic acid and samples were allowed to stand at $25^{\circ} \mathrm{C}$ for 1 hour. After centrifugation at 3,000 $g\left(\mathrm{r}_{\mathrm{av}}=7.0 \mathrm{~cm}\right)$ for $15 \mathrm{~min}$, the supernatant was filtered through Inlab type 10 paper and its absorbance was determined at $280 \mathrm{~nm}$. Controls in which trichloroacetic acid was added to the filtrate before adding the substrate were prepared in parallel for all treatments. A mixture containing $1 \mathrm{ml}$ buffer was used as blank and treated in the same manner. Enzymatic activity was calculated as the variation in supernatant absorbance during the period of incubation $\mathrm{x} 10$.

\section{Determination of proteolytic activity against elastin}

The elastolytic activity of the filtrate was determined by the method used by St. Leger et al. (22), with the following modifications. A reaction mixture containing $4 \mathrm{ml}$ of an elastin Congo red (Sigma) suspension, $1.5 \mathrm{mg} \mathrm{ml}^{-1}$ in $0.05 \mathrm{M}$ Tris- $\mathrm{HCl}$ buffer, $\mathrm{pH} 8.0$, and $1 \mathrm{ml}$ of the filtrate was prepared. The mixture was shaken vigorously for $10 \mathrm{sec}$, incubated at $30^{\circ} \mathrm{C}$ for 30 min without shaking, and then centrifuged at $5,000 \mathrm{~g}\left(\mathrm{r}_{\mathrm{av}}=7.0 \mathrm{~cm}\right)$ for $10 \mathrm{~min}$. The supernatant was filtered through Inlab type 10 paper and absorbance was determined at $450 \mathrm{~nm}$. Controls in which the substrate was excluded from the reaction mixture were carried out in parallel for all treatments. Buffer was used as the blank. Enzymatic activity was determined as the variation in supernatant absorbance during the incubation period $\mathrm{x} 100$. 


\section{Determination of residual glucose}

Residual glucose present in the medium throughout growth was determined by the method of Nelson (12).

\section{Determination of dry mass and autolysis}

The mycelium separated by filtration was dried at $70^{\circ} \mathrm{C}$ for $72 \mathrm{~h}$. Autolysis was determined by the methods of Reyes and Lahoz (16). The degree of autolysis was defined as percent loss of mycelial dry mass from the day of maximum growth, taken as the initial point, to the day when the sample was evaluated.

\section{Efficiency of growth}

The efficiency of growth was estimated by the economic coefficient (EC) according to the following formula:

$\mathrm{EC}=$ Mycelial dry weigh (mg)/ Quantity of carbon source consumed (mg)

\section{RESULTS AND DISCUSSION}

\section{Growth and autolysis}

Table 1 shows the production of biomass by strains 22 and CLII growing on medium containing glucose as the only carbon source. Maximum biomass production ocurred on the $5^{\text {th }}$ day of incubation for both strains. The maximum biomass production of strain CLII ( $71.5 \mathrm{mg} /$ flask) was lower, corresponding to $81.7 \%$ of the maximum production reached by strain 22 ( $87.5 \mathrm{mg} /$ flask). Exogenous glucose depletion ocurred at about the $5^{\text {th }}$ day of growth and on the $7^{\text {th }}$ day both strains presented autolysis process. The beginning of autolysis after depletion of the exogenous carbon source has been observed to a greater or lesser degree in various species of filamentous fungi $(1,9,10,11,17,18)$. After 16 days of growth (11 days of autolysis), strain 22 presented $52.4 \%$ autolysis and strain CLII presented $61.4 \%$ autolysis. These rates of autolysis are observed only when degradation of cytoplasm and cell walls occurs (16). Table 2 shows the efficiency of the utilization of the substrate from the calculation of the economic coefficient. It can be seen that the economic coefficient varied considerably as a function of the time of culture development. The highest economic coefficient was observed on the $5^{\text {th }}$ day for strain 22 when the highest biomass production and total utilization of exogenous substrate occurred. For strain CLII, the highest
Table 1. Variations in $\mathrm{pH}$, glucose availability and degree of autolysis during incubation of strains 22 and CLII in medium containing $0.5 \%(\mathrm{w} / \mathrm{v})$ glucose as the only carbon source.

\begin{tabular}{ccccc}
\hline $\begin{array}{c}\text { Time } \\
(\text { days })\end{array}$ & $\begin{array}{c}\text { Dry mass } \\
(\mathrm{mg})\end{array}$ & $\begin{array}{c}\text { Degree of } \\
\text { autolysis } \\
(\%)^{\mathrm{a}}\end{array}$ & $\begin{array}{c}\text { Glucose in } \\
\text { the medium } \\
(\mathrm{mg} / \mathrm{ml})\end{array}$ & $\begin{array}{c}\mathrm{pH} \text { of } \\
\text { the medium }\end{array}$ \\
\hline \multicolumn{5}{c}{ Strain 22} \\
0 & - & - & $5.19 \pm 0.00$ & $6.50 \pm 0.00$ \\
1 & $20.5 \pm 5.1$ & - & $3.66 \pm 0.19$ & $6.63 \pm 0.02$ \\
2 & $31.5 \pm 6.1$ & - & $3.08 \pm 0.15$ & $6.73 \pm 0.02$ \\
3 & $45.3 \pm 7.4$ & - & $1.72 \pm 0.23$ & $6.86 \pm 0.07$ \\
5 & $87.5 \pm 8.7$ & - & $0.04 \pm 0.00$ & $7.82 \pm 0.06$ \\
7 & $82.6 \pm 4.6$ & 5.6 & $0.03 \pm 0.00$ & $7.94 \pm 0.04$ \\
9 & $63.9 \pm 0.5$ & 27.0 & $0.03 \pm 0.00$ & $8.14 \pm 0.04$ \\
13 & $51.8 \pm 4.1$ & 40.8 & $0.03 \pm 0.00$ & $8.27 \pm 0.02$ \\
16 & $41.6 \pm 2.5$ & 52.4 & $0.02 \pm 0.00$ & $8.40 \pm 0.05$ \\
\hline \multicolumn{5}{c}{} \\
0 & & Strain CLII & \\
1 & $18.6 \pm 3.1$ & - & $3.77 \pm 0.19$ & $6.64 \pm 0.01$ \\
2 & $36.3 \pm 2.0$ & - & $2.75 \pm 0.12$ & $6.73 \pm 0.02$ \\
3 & $61.5 \pm 12.0$ & - & $1.57 \pm 0.56$ & $7.82 \pm 0.06$ \\
5 & $71.5 \pm 8.5$ & - & $0.03 \pm 0.00$ & $8.02 \pm 0.01$ \\
7 & $66.2 \pm 11.8$ & 7.4 & $0.02 \pm 0.00$ & $8.22 \pm 0.04$ \\
9 & $37.2 \pm 1.0$ & 48.0 & $0.02 \pm 0.00$ & $8.33 \pm 0.12$ \\
13 & $26.7 \pm 0.6$ & 62.7 & $0.02 \pm 0.00$ & $8.63 \pm 0.07$ \\
16 & $27.6 \pm 1.7$ & 61.4 & $0.02 \pm 0.00$ & $8.74 \pm 0.04$ \\
\hline
\end{tabular}

Each result corresponds to the mean of three replicates.

${ }^{\text {a }}$ Autolysis was calculated with respect to the highest production of dry mass.

economic coefficient was observerved on the $3^{\text {rd }}$ day, when the biomass production was $86.0 \%$ and the utilization of exogenous substrate was $70.0 \%$ of the total.

According to Reyes and Lahoz (16), during growth there is a balance between the synthesis and lysis of the polymers that form the walls. The lack of nutrients may cause the cessation of synthesis, provoking a shift of this balance toward lysis of hyphal walls, with the consequent beginning of autolysis. Although glucose, when present in the medium, represses the synthesis of hydrolytic enzymes, it has been shown that, after the beginning of autolysis, the production of hydrolytic enzymes is induced by the presence of soluble oligomers and monomers present in the medium. These substances are derived from the degradation of the cell wall and are found at low concentrations in the culture fluid due to the turnover of substances that occurs during autolysis (15). 
Table 2. Glucose utilization by strains 22 and CLII in submerged cultures.

\begin{tabular}{cccccccc}
\hline & \multicolumn{3}{c}{ Strain 22 } & & \multicolumn{3}{c}{ Strain CLII } \\
\cline { 2 - 3 } $\begin{array}{c}\text { Incubation } \\
\text { time (days) }\end{array}$ & $\begin{array}{c}\text { Glucose } \\
\text { utilized }(\mathrm{mg})\end{array}$ & $\begin{array}{c}\text { Mycelium } \\
\text { formed }(\mathrm{mg})\end{array}$ & $\begin{array}{c}\text { Economic } \\
\text { coefficient }\end{array}$ & $\begin{array}{c}\text { Glucose } \\
\text { utilized }(\mathrm{mg})\end{array}$ & $\begin{array}{c}\text { Mycelium } \\
\text { formed (mg) }\end{array}$ & $\begin{array}{c}\text { Economic } \\
\text { coefficient }\end{array}$ \\
\hline 1 & $50.5 \pm 6.4$ & $20.5 \pm 5.1$ & $40.2 \pm 6.2$ & & $46.8 \pm 6.4$ & $18.6 \pm 3.1$ & $40.0 \pm 2.0$ \\
2 & $69.6 \pm 5.0$ & $31.5 \pm 6.1$ & $45.0 \pm 5.5$ & & $80.6 \pm 4.0$ & $36.3 \pm 2.0$ & $45.5 \pm 4.5$ \\
3 & $114.6 \pm 7.7$ & $45.3 \pm 7.4$ & $39.5 \pm 6.3$ & & $119.6 \pm 18.5$ & $61.5 \pm 12.0$ & $51.0 \pm 4.9$ \\
5 & $170.0 \pm 0.1$ & $87.5 \pm 8.7$ & $51.5 \pm 5.1$ & & $170.5 \pm 0.0$ & $71.5 \pm 8.5$ & $41.9 \pm 5.0$ \\
7 & $170.2 \pm 0.0$ & $82.6 \pm 4.6$ & $48.5 \pm 2.7$ & & $170.5 \pm 0.1$ & $66.2 \pm 11.8$ & $38.8 \pm 6.9$ \\
9 & $170.3 \pm 0.1$ & $63.9 \pm 0.5$ & $37.5 \pm 0.3$ & & $170.6 \pm 0.0$ & $37.2 \pm 1.0$ & $21.8 \pm 0.6$ \\
13 & $170.5 \pm 0.0$ & $51.8 \pm 4.1$ & $30.4 \pm 2.4$ & & $170.6 \pm 0.1$ & $26.7 \pm 0.6$ & $15.6 \pm 0.4$ \\
16 & $170.5 \pm 0.1$ & $41.6 \pm 2.5$ & $24.4 \pm 1.5$ & & $170.8 \pm 0.1$ & $27.6 \pm 1.7$ & $16.1 \pm 1.0$ \\
\hline
\end{tabular}

Each result represents the mean of three replicates.

Table 3. Variations in $\mathrm{pH}$ and in the proteolytic activity of the filtrate and degree of autolysis during incubation of strains 22 and CLII in medium containing $0.5 \%(\mathrm{w} / \mathrm{v})$ casein as the only carbon and nitrogen source.

\begin{tabular}{cccccc}
\hline $\begin{array}{c}\text { Incubation } \\
\text { time (days) }\end{array}$ & $\begin{array}{c}\text { Dry mass } \\
(\mathrm{mg})\end{array}$ & $\begin{array}{c}\text { Extent of } \\
\text { autolysis }(\%)^{\mathrm{a}}\end{array}$ & $\begin{array}{c}\text { Proteolytic } \\
\text { activity vs. casein }^{\mathrm{b}}\end{array}$ & $\begin{array}{c}\text { Proteolytic } \\
\text { activity vs. elastin }^{\mathrm{c}}\end{array}$ & $\begin{array}{c}\mathrm{pH} \text { of the } \\
\text { medium }^{\text {a }}\end{array}$ \\
\hline & & & & & \\
1 & $27.2 \pm 0.5$ & - & Strain 22 & \\
3 & $72.6 \pm 0.3$ & - & $0.14 \pm 0.08$ & $0.20 \pm 0.16$ & $6.45 \pm 0.00$ \\
5 & $103.4 \pm 0.6$ & - & $0.35 \pm 0.15$ & $0.40 \pm 0.14$ & - \\
7 & $102.9 \pm 7.2$ & 0.4 & $0.51 \pm 0.13$ & $0.34 \pm 0.22$ & $7.78 \pm 0.08$ \\
9 & $90.5 \pm 3.2$ & 12.5 & $1.33 \pm 0.17$ & $1.03 \pm 0.14$ & $8.41 \pm 0.03$ \\
13 & $70.3 \pm 4.4$ & 32.0 & $1.50 \pm 0.07$ & $1.40 \pm 0.18$ & $8.43 \pm 0.06$ \\
16 & $58.4 \pm 1.5$ & 43.5 & $1.15 \pm 0.14$ & $1.14 \pm 0.14$ & $8.53 \pm 0.02$ \\
& & & & $1.22 \pm 0.43$ & $8.57 \pm 0.09$ \\
\hline & & & & & \\
3 & $78.9 \pm 4.2$ & - & $0.05 \pm 0.03$ & $0.19 \pm 0.04$ & $6.46 \pm 0.02$ \\
5 & $91.7 \pm 4.2$ & - & $0.38 \pm 0.24$ & $0.22 \pm 0.17$ & - \\
7 & $58.7 \pm 1.5$ & 36.0 & $7.21 \pm 0.92$ & $3.25 \pm 0.39$ & $8.32 \pm 0.12$ \\
9 & $45.2 \pm 4.6$ & 50.7 & $5.48 \pm 0.84$ & $2.79 \pm 0.19$ & $8.59 \pm 0.05$ \\
13 & $43.7 \pm 1.6$ & 52.3 & $3.22 \pm 0.14$ & $2.12 \pm 0.25$ & $8.77 \pm 0.05$ \\
16 & $39.0 \pm 1.7$ & 57.5 & $2.33 \pm 0.48$ & $1.84 \pm 0.13$ & $8.67 \pm 0.06$ \\
\hline
\end{tabular}

Each result represents the mean of three replicates.

${ }^{a}$ Autolysis was calculated with respect to the highest dry mass production.

${ }^{\mathrm{b}}$ Activity determined by the variation in absorbance at $280 \mathrm{~nm}$ during the period of incubation ( $5 \mathrm{~min}$.).

c Activity determined by the variation in absorbance at $450 \mathrm{~nm}$ during the period of incubation ( $30 \mathrm{~min}$.).

Table 3 shows the production of biomass by strains 22 and CLII growing on medium containing casein as the only source of carbon and nitrogen. Again, the maximum production of strain $22(103.4 \mathrm{mg} /$ flask $)$ was higher than the production of strain CLII $(91.7 \mathrm{mg} /$ flask). Both presented a production peak on the $5^{\text {th }}$ day of growth. The biomass production data presented in Fig. 1 show that casein is a carbon source that can be used more efficiently by M. anisopliae than glucose, favoring a more rapid growth and a greater biomass production. Similar results have been reported for other species of filamentous fungi (5). Using respirometric experiments, we observed that casein and hydrolyzed casein accelerate germination, reduce the duration of the lag phase and increase the growth rate compared to glucose (umpublished data). 


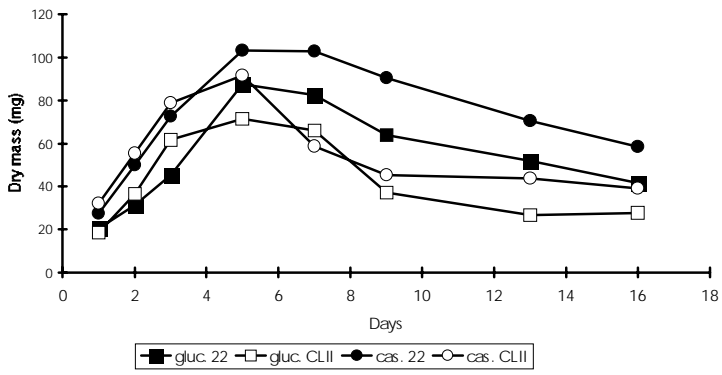

Figure 1. Growth curves for strains 22 and CLII in media containing $0.5 \%$ glucose or casein $(\mathrm{w} / \mathrm{v})$. Each point represents the mean of three replicates. The standard errors of the means were 3.1 for strain 22 in glicose, 3.9 for strain CLII in glicose, 2.0 for strain 22 in casein and 1.8 for strain CLII in casein.

Tables 1 and 3 show that in the culture media used there was a progressive increase in $\mathrm{pH}$ both during the growth phase and the autolysis phase of the two strains. Santamaria and Reyes (20), in a study of protease production during autolysis in different species of filamentous fungi, observed that autolysis occurred at $\mathrm{pH}$ values between 6.5 and 8 . According to these investigators, the fact that autolysis occurs in these fungi at slightly alkaline $\mathrm{pH}$ may be related to the production of neutral and alkaline proteases by fungi from the major taxonomic groups. The main protease produced by $M$. anisopliae, $\operatorname{Pr} 1$, has a $\mathrm{pH}$ optimum of about 8 (22). The progressive increase in medium $\mathrm{pH}$ during autolysis of $M$. anisopliae cultures was previously observed by Campbell et al. (3).

\section{Protease production}

The caseinolytic activity of the $M$. anisopliae culture filtrates is mainly due to the presence of two proteases, Pr1 and Pr2 (22), both capable of hydrolyzing casein. The elastolytic activity is due to the action of Pr1 which, in addition to having caseinolytic and elastolytic activity, has a strong activity against insect cuticles. $\operatorname{Pr} 1$ is being indicated as one of the factors responsible for the virulence of the fungus $(4,23)$.

In a previous study we determined the proteolytic activity of $16 \mathrm{M}$. anisopliae strains after a fixed time of growth (2). The results permitted us to identify two contrasting strains: strain CLII, with high proteolytic activity, and strain 22 , with low proteolytic activity. However, we could not determine whether this difference persisted throughout growth and autolysis or whether there was variation in the kinetics of enzyme production between strains. This information was obtained only by monitoring protease production

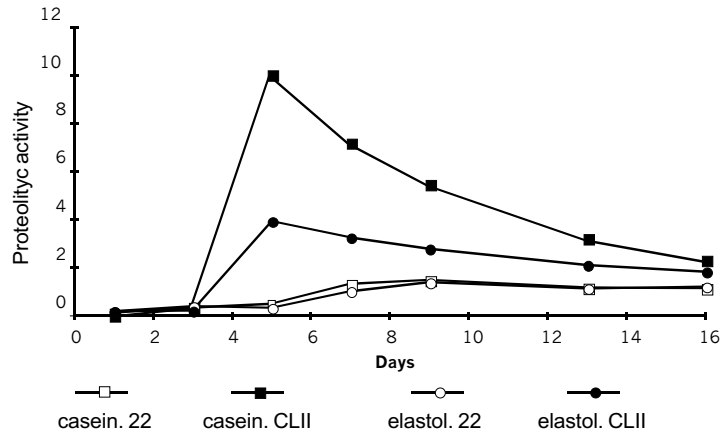

Figure 2. Caseinolytic and elastolytic activities present in the culture filtrates of strains 22 and CLII grown on medium containing $0.5 \%$ casein $(\mathrm{w} / \mathrm{v})$ as the single carbon source.Caseinolytic activity was calculated as the variation in absorbance at $280 \mathrm{~nm} \times 10$ during the incubation period $(15 \mathrm{~min})$. Elastolytic activity was calculated as the variation in absorbance at $450 \mathrm{~nm} \times 100$ during the incubation period $(30 \mathrm{~min})$. Each point represents the mean of three replicates.

throughout the steps of strain growth and autolysis. Table 3 and Fig. 2 show the variations in the proteolytic activities present in the culture filtrates of the two strains grown on medium containing casein as the only carbon and nitrogen source. Up to the $2^{\text {nd }}$ day the strains presented similar proteolytic activities. Starting at that time, the proteolytic activities of strain CLII were rapidly increased, reaching a maximum at about 5 days, when the highest production of biomass was also observed. A progressive decrease in proteolytic activity occurred thereafter. Protease production by strain 22 increased in a discrete manner, reaching a peak at about 9 days, already during the autolysis phase, and decreasing slowly until the end of the experiment. Studies on other species of fungi have shown that in most cases proteolytic activity increases with the beginning of autolysis; however, it is not uncommon for the maximum proteolytic activity to coincide with the growth phase $(5,20)$. The highest caseinolytic activity achieved by strain CLII was on average 6.7 times higher than that achieved by strain 22. The highest elastolytic activity observed in strain CLII was on average 2.8 times higher than that observed in strain 22. Fig. 2 shows that the ratios of the proteolytic activities of the two strains varied considerably along the various physiological stages of the cultures. The ratio of the caseinolytic activities of strains CLII and 22 on the $5^{\text {th }}$ day was 19.78 (maximum), and was decreased to 2.03 (minimum) on the $16^{\text {th }}$ day. Although strain 22 never presented a higher proteolytic activity than strain CLII, the variation in the ratio of their activities along 
development clearly shows that the difference in the growth curves and in the kinetics of enzyme production may impair the evaluation of the trait if proteolytic activity is determined only once during culture development.

\section{ACKNOWLEDGMENTS}

This work was supported in part by the following Brazilian organizations: CNPq, FAEP, CAPES, PADCT II-FINEP, CNPq-Blue Ribbon.

\section{RESUMO}

\section{Produção de protease durante o crescimento e análise de culturas submersas de Metarhizium anisopliae}

O crescimento e a autólise de duas linhagens do deuteromiceto entomopatogênico Metarhizium anisopliae var. anisopliae foram avaliados em meio contendo caseína ou glicose como fonte de carbono. Foram determinados parâmetros como o coeficiente econômico e o grau de autólise apresentado pelas linhagens. A produção de protease foi determinada durante todas as fases do crescimento e da autólise das culturas, em meio indutor da produção de proteases (meio contendo caseína como única fonte de carbono e de nitrogênio). Pôde-se verificar que o fungo foi capaz de utilizar a caseína como fonte de carbono/energia de maneira mais eficiente do que a glicose. A autólise apresentada pelas linhagens foi intensa em ambas as condições de crescimento, alcançando até $62,7 \%$ da massa seca produzida, e se iniciou logo após o esgotamento da fonte exógena de carbono. A relação entre as atividades proteolíticas apresentadas pelas duas linhagens avaliadas variou de maneira significativa (máxima de 19,78 no $5^{\circ}$ dia e mínima de 1,55 no $16^{\circ}$ dia de incubação) durante as diversas fases do crescimento e da autólise, deixando claro que as diferenças verificadas entre as curvas de crescimento e entre as cinéticas da produção das enzimas podem influenciar decisivamente no processo de seleção de linhagens para a produção de proteases.

Palavras-chave: Metarhizium anisopliae, produção de protease, crescimento de fungo, autólise de fungo, fungo entomopatogênico.

\section{REFERENCES}

1. Alfonso, C.; Martinez, M.J.; Reyes, F. Degradation of chitosan in the autolysis of mucorales. Mycol. Res., 95: 217-219, 1991.

2. Braga, G.U.L.; Messias, C.L.; Vencovsky, R. Estimates of genetic parameters related to protease production by Metarhizium anisopliae. J. Invertebr. Pathol., 64: 6-12, 1994.

3. Campbell, R.K.; Perring, T.M.; Barnes, G.L.; Eikenbary, R.D.; Gentry, C.R. Growth and sporulation of Beauveria bassiana and Metarhizium anisopliae on media containing various amino acids. J. Invertebr. Pathol., 31: 289-295, 1978.

4. Goettel, M.S.; St. Leger, R.J.; Rizzo, N.W.; Staples, R.C.; Roberts, D.W. Ultrastructural localization of a cuticledegrading protease produced by the entomopathogenic fungus Metarhizium anisopliae during penetration of host (Manduca sexta) cuticle. J. Gen. Microbiol., 135: 2233-2239, 1989.

5. Kalisz, H.M.; Moore, D.; Wood, D.A. Protein utilization by basidiomycete fungi. Trans. Br. Mycol. Soc., 86: 519-525, 1986.

6. Kucera, M. Proteases from the fungus Metarhizium anisopliae toxic for Galleria mellonella larvae. J. Invertebr. Pathol., 35: 304-310, 1980.

7. Kucera, M. The production of toxic protease by the entomopathogenous fungus Metarhizium anisopliae in submerged culture. J. Invertebr. Pathol., 38: 33-38, 1981.

8. Kucera, M. 1984. Partial purification and properties of Galleria mellonella larvae proteolytic inhibitors acting on Metarhizium anisopliae toxic protease. J. Invertebr. Pathol., 43: 190-196, 1984.

9. Lahoz, R.; Ibeas, J.G. The autolysis of Aspergillus flavus in an alkaline medium. J. Gen. Microbiol., 53: 101-108, 1968.

10. Lahoz, R.; Miralles, M. Influence of the level of the carbon source on the autolysis of Aspergillus niger. J. Gen. Microbiol., 60: 271-276, 1970.

11. Lahoz, R.; Reyes, F.; Martinez, M.J.; Jimeno, L. Effect of the $\mathrm{pH}$ on the degree of autolysis of Aspergillus niger. Can. J. Bot., 57: 1901-1903, 1979.

12. Nelson, N. A photometric adaptation of the Somogy method for the determination of glucose. J. Biol. Chem., 153: 375-380, 1944.

13. Oliveira, N.T.; Messias, C.L. Variability of strains of Metarhizium anisopliae Var. anisopliae (Metsch.) Sorokin in terms of protein content and spore germination. Rev Microbiol., 27: 268-272, 1996.

14. Pontecorvo, G.; Roper, J.A.; Hemmons, L.M.; McDonald, K.F.; Bufton, A.W.J. The genetics of Aspergillus nidulans. Adv. Gen., 5: 141-238, 1953.

15. Reyes, F.; Calatayud, J.; Martínez, M.J. Chitinolytic activity in the autolysis of Aspergillus nidulans. FEMS Microbiol. Lett., 49: 239-243, 1988.

16. Reyes, F.; Lahoz, R. Variation in lysis of walls of Sclerotinia fructigena with age of culture. J. Gen. Microbiol., 98: 607610, 1977.

17. Reyes, F.; Lahoz, R.; Cornago P. Autolysis of Neurospora crassa in different culture conditions and release of $B-N$ Acetyl-Glucosaminidase and chitinase. Trans. Br. Mycol. Soc., 68: 357-361, 1977.

18. Reyes, F.; Lahoz, R.; Moreno, A.V. Synthesis of 1,3-ßglucanase and $\mathrm{B}-\mathrm{N}$-acetylglucosaminidase during autolysis of Neurospora crassa. J. Gen. Microbiol., 126: 347-353, 1981.

19. Rosato, Y.B.; Messias, C.L.; Azevedo, J. L. Production of extracellular enzymes by isolates of Metarhizium anisopliae J. Invertebr. Pathol., 38: 1-3, 1981.

20. Santamaria, F.; Reyes, F. Proteases produced during autolysis of filamentous fungi. Trans. Br. Mycol. Soc., 91: 217-220, 1988. 
21. Söderhäll, K.; Unestam, T. Properties of extracellular enzymes from Amphanomyces astaci and their relevance in the penetration process of crayfish cuticle. Physiol. Plant., 35: 140-146, 1975.

22. St. Leger, R.J.; Charnley, A.K.; Cooper, R.M. Characterization of cuticle-degrading proteases produced by the entomopathogen Metarhizium anisopliae. Arch. Biochem. Biophys., 253: 221-232, 1987.
23. St. Leger, R.J.; Cooper, R.M.; Charnley, A.K. Production of cuticle-degrading enzymes by the entomopathogen Metarhizium anisopliae during infection of cuticles from Colliphora vomitoria and Manduca sexta.J. Gen. Microbiol., 133: 1371-1382, 1987. 